\title{
ANALISIS DAN PERBAIKAN UNTUK MEMINIMASI DEFECT PADA PROSES (STUDI KASUS DI PT ABO FARM)
}

\author{
${ }^{1}$ Ayren Tantri Sofan, ${ }^{2}$ Rino Andias Anugraha, ${ }^{3}$ Pratya Poeri Suryadhini, \\ ${ }^{1,2,3}$ Program Studi Teknik Industri, Departemen Rekayasa Industri, Telkom University \\ ${ }^{1}$ riritantrisofan@gmail.com, ${ }^{2}$ rinoandias@telkomuniversity.ac.id, ${ }^{3}$ pratya@telkomuniversity.ac.id
}

\begin{abstract}
Abstrak-PT. Abo Farm adalah perusahaan yang bergerak di bidang pertanian dan rumah kemasarn sayuran. Persaingan ketat dengan banyak perusahaan sejenis mendorong PT Abo Farm agar terus meningkatkan kualitas produk-produknya. Salah satu cara untuk melakukannya adalah terus meningkatkan kualitas produk kacang yang dikirim agar memperoleh zero defect. Peningkatan kualitas dan pencegahan defect dari produk kacang yang terjadi saat proses pengangkutan di daerah pengumpulan. Pemilihan produk didasarkan pada persentase kacang defect yang mencapai titik tertinggi pada Januari-Desember 2012. Rata-rata persentase produk defect mencapai lebih dari $1 \%$ dalam satu periode. Oleh karena itu, kualitas produk akan ditingkatkan dengan metode Six Sigma untuk mencegah dan mengurangi tingkat produk defect pada kacang. Tahapan dalam metode Six Sigma terdiri dari lima tahap yang mendefinisikan, mengukur, menganalisa, memperbaiki, dan kontrol (DMAIC). Dalam mendefinisikan fase, diidentifikasi terdapat lima buah CTQ yang potensial berpengaruh pada kualitas produk. Pada tahap pengukuran ditekankan bahwa proses pengiriman (pengangkutan) tidak stabil dan kemampuan dari proses ditandai oleh tingkat Sigma 3.67 dengan 15163 DPMO. Berdasarkan analisis fase, ditemukan lima potensi penyebab kerusakan yang menjadi prioritas untuk diperbaiki. Usulan perbaikan yang diberikan maksimum berat bawaan diatur oleh operator, mendefinisikan dan merancang metode standar pengangkatan yang tepat dan aman, ergonomis untuk menentukan ukuran kompartemen, menambahkan bagian pada bagian pada perusahaan bertanggung jawab atas kualitas proses dan kualitas produk kacang dan melakukan pelatihan bagi petani panen.
\end{abstract}

Kata Kunci-Quality, Defect, Six Sigma, CTQ, DPMO

\section{Pendahuluan}

Pertanian adalah pemanfaatan sumber daya hayati oleh manusia untuk menghasilkan makanan, bahan baku industri atau sumber energi, serta untuk mengelola lingkungan mereka. Pemanfaatan sumber daya alam hayati, termasuk di bidang pertanian umumnya dipahami sebagai budidaya tanaman atau pertanian (Dimas Setiawan: 2008). Pertanian di Indonesia dibagi menjadi dua, yaitu tanaman pertanian dan tanaman pangan. Tanaman pertanian seperti kakao, kelapa sawit dan tanaman lainnya sementara makanan seperti jagung, sayuran, beras, dan buah-buahan lainnya.

Salah satu perusahaan yang bergerak di bidang pertanian adalah PT. FARM ABO terletak di Ciwidey, Jawa
Barat. PT.ABO FARM merupakan perusahaan yang berfokus pada penjualan di biji sayuran. Dalam pengolahan sayur kacang itu sendiri, ada beberapa proses yang akan menjadi salah satu yang merupakan penerimaan dari biji kacang kolektor yang menggunakan plastik dalam proses loading yang akan diambil dengan menggunakan sebuah truk pickup.

Selama proses loading fraktur yang terjadi akibat kacang pada kacang ditolak dan dianggap sebagai menolak. Selama PT.Abo Pertanian tidak menindaklanjuti kacang cacat ditolak oleh eksportir. Kacang ditolak kemudian dijual ke pasar dengan harga murah. Bahkan, jika perusahaan mencari penyebab mengapa kacang ditolak (cacat) maka pendapatan perusahaan akan meningkat dibandingkan dengan rakyat tradisional untuk menjual ke pasar. Oleh karena itu kita perlu cara untuk mengurangi jumlah kacang yang menolak eksportir (cacat) dengan menggunakan metode Six Sigma, yang dimulai dengan mendefinisikan kebutuhan eksportir, mengklasifikasikan penyebab buncis dan atasnya dengan administrasi menolak perbaikan yang diusulkan.

Mendefinisikan eksportir diperlukan sehingga perusahaan perlu mengetahui jenis dan karakteristik kacang yang diinginkan, sehingga dapat memberikan perlakuan yang berbeda dan memberikan kacang yang sesuai dengan kebutuhan Anda. Jadi melakukan penelitian pada PT. Abo Pertanian untuk merancang perbaikan diharapkan dapat mengurangi jumlah kacang yang ditolak dan menguntungkan perusahaan. $55 \mathrm{~kg} /$ kantong plastik. Salah satu lembaga yang menangani masalah kesehatan dan keselamatan di AS yang NIOSH (National Institute of Occupational Safety and Health) menyatakan bahwa batas aman untuk beban angkat maksimum adalah $23 \mathrm{~kg}$. Oleh karena itu, dapat dilihat bahwa beban diangkat oleh operator melebihi batas aman maksimum.

\section{Metodologi Penelitian}

Penelitian ini bertujuan untuk meminimalkan kerusakan yang terjadi pada PT. Abo Pertanian. Gambar III.1 menggambarkan model konseptual penelitian, model konseptual digunakan untuk menentukan masalah penelitian dan mengidentifikasi variabel yang memiliki hubungan satu sama lain. Kritis Untuk Kualitas (CTQ) unsur-unsur yang secara langsung berhubungan dengan kebutuhan dan kepuasan eksportir. CTQ dalam penelitian ini diperoleh langsung dari 
perusahaan, perusahaan memiliki spesifikasi standar, karakteristik dan persyaratan pengobatan sesuai dengan kacang yang telah ditetapkan oleh eksportir. Perusahaan menetapkan bahwa output luar eksportir standar adalah hasil dari cacat dari pengiriman.

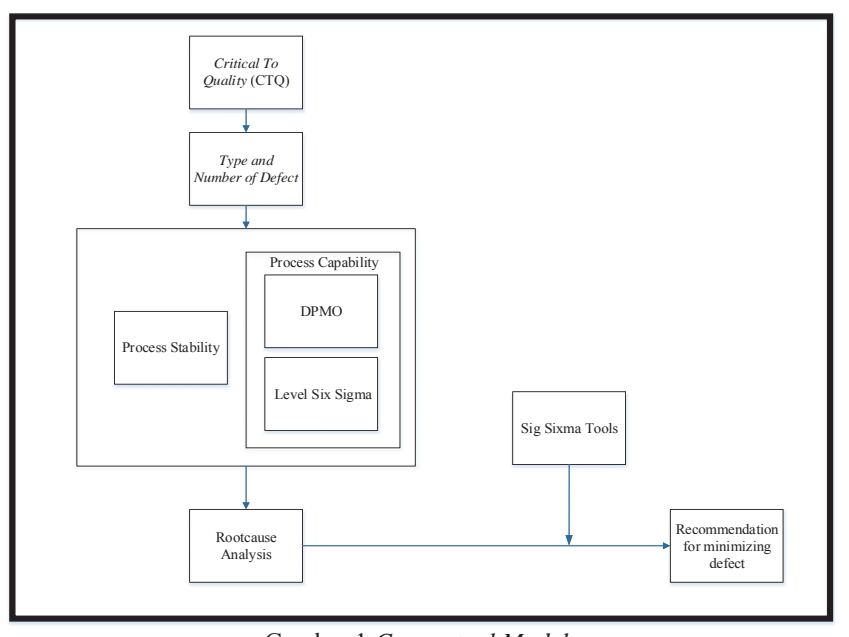

Gambar 1 Conceptual Model

Penelitian ini bertujuan untuk meminimalkan kerusakan yang terjadi pada PT. Abo Pertanian. Gambar 1 menggambarkan model konseptual penelitian, model konseptual digunakan untuk menentukan masalah penelitian dan mengidentifikasi variabel yang memiliki hubungan satu sama lain. Kritis Untuk Kualitas (CTQ) unsur-unsur yang secara langsung berhubungan dengan kebutuhan dan kepuasan eksportir. CTQ dalam penelitian ini diperoleh langsung dari perusahaan, perusahaan memiliki spesifikasi standar, karakteristik dan persyaratan pengobatan sesuai dengan kacang yang telah ditetapkan oleh eksportir. Perusahaan menetapkan bahwa output luar eksportir standar adalah hasil dari cacat dari pengiriman.

Identifikasi data data pengaduan yang diperoleh dari data historis perusahaan lakukan untuk mendapatkan CTQ. Dari data keluhan yang diperoleh, dapat diketahui jumlah cacat yang terjadi pada bulan Januari dan Desember 2012. Cacat yang dimaksud adalah kegagalan untuk memberikan apa yang diinginkan oleh eksportir dalam hal jumlah dan jenis. Cacat data yang digunakan dalam perhitungan stabilitas proses yang merupakan ukuran stabilitas dalam proses pengumpulan biji pengiriman ke perusahaan. Selain perhitungan kemampuan proses juga dilakukan untuk menghasilkan kacang sesuai dengan spesifikasi yang telah ditetapkan dinyatakan oleh banyak cacat per satu juta kesempatan (DPMO) dan dilanjutkan dengan perhitungan Sigma Tingkat perusahaan yang ada. Faktor-faktor yang menyebabkan akar masalah dapat dianalisis untuk mengetahui akar penyebab cacat. Setelah perbaikan yang diusulkan dapat dibuat dalam hal meningkatkan kualitas pengiriman kinerja pengiriman kacang kolektor ke perusahaan

\section{Pengumpulan Dan Pengolahan Data}

Pengumpulan data dalam penelitian ini, dilakukan dengan menggunakan dua jenis data yaitu data primer dan data sekunder. Data primer adalah data yang diperoleh melalui pengamatan langsung proses bisnis perusahaan. Pengamatan yang dilakukan dalam bentuk wawancara hasil dengan perusahaan tentang jenis kerusakan yang terjadi. Sedangkan data sekunder adalah data yang sudah ada dalam bentuk profil perusahaan perusahaan yang jenis dan jumlah data yang cacat.

Tahap pertama yang dilakukan adalah menentukan. Dalam tahap ini kita perlu menentukan pemilihan objek target dari enam sigma, penting untuk kualitas dan pemetaan proses.

Pemilihan objek target dari enam sigma dalam penelitian ini adalah di daerah pengumpulan dan fokus pada biji sayuran hanya karena berdasarkan pengamatan dan wawancara dengan para pekerja perusahaan, pengumpulan daerah merupakan area yang penting yang mempengaruhi kejadian produk cacat. Selain itu, kacang-kacangan adalah salah satu sayuran yang memiliki nilai jual tinggi dan menjadi prioritas utama bagi perusahaan.

Kritis Untuk Kualitas (CTQ) diperoleh berdasarkan spesifikasi yang diinginkan oleh pelanggan. Dalam hal ini, data CTQ diperoleh melalui wawancara dengan perusahaan ukuran yaitu kesesuaian kacang, bentuk kacang, kualitas kacang, kebersihan kacang dan terakhir adalah integritas kacang.

Model proses pemetaan yang digunakan dalam penelitian ini adalah SIPOC (Suppliers - Input - Proses - Output Pelanggan). Diagram SIPOC untuk proses delivey kacang akan digambarkan sebagai berikut Gambar 2.

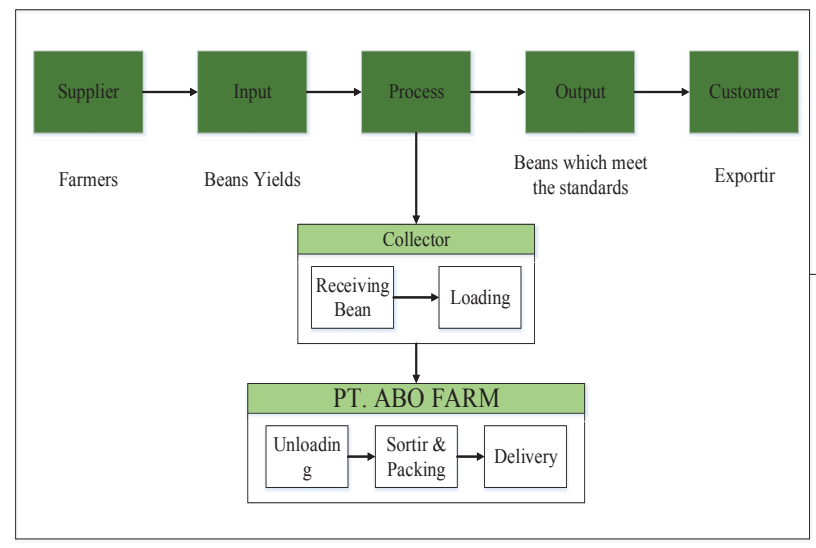

Gambar 2 PT Abo Farm SIPOC Diagram

Tahap kedua yang mengikuti adalah ukuran. Dalam tahap ini, akan diukur terhadap stabilitas dan kemampuan proses di perusahaan.

Stabilitas adalah ukuran stabilitas proses dari proses yang berkelanjutan. Sebuah proses dapat dikatakan stabil jika proses berada di batas kendali yang berarti proses memiliki variasi dalam batas yang wajar. Untuk menentukan stabilitas suatu peta kendali proses yang digunakan peta P (P Chart). Perhitungan proses stabilitas dalam jangka waktu pengiriman mengumpulkan biji dari Januari hingga Desember ditunjukkan pada Gambar 3. 


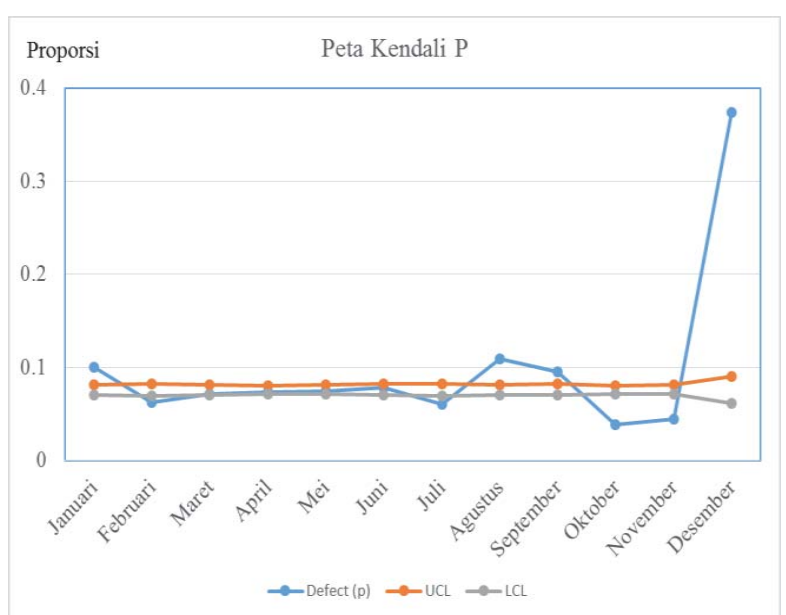

Gambar 3 P Control Chart for Bean's Product

Pengukuran kemampuan proses yang dilakukan untuk mengukur kemampuan proses untuk menghasilkan suatu produk atau jasa yang sesuai dengan kebutuhan Anda atau spesifikasi yang diharapkan oleh konsumen. Ini dilakukan untuk mendapatkan nilai DPMO dan Sigma Tingkat Pengukuran. Berdasarkan pengukuran stabilitas yang telah dilakukan, proses pengiriman biji dikenal berada dalam keadaan yang tidak stabil. Namun, penghitungan ini masih bisa dilakukan untuk menentukan kinerja proses saat ini untuk memenuhi spesifikasi pelanggan. Berikut ini adalah nilai sigma ketika dipetakan ke dalam grafik seperti digambarkan pada Gambar 4.

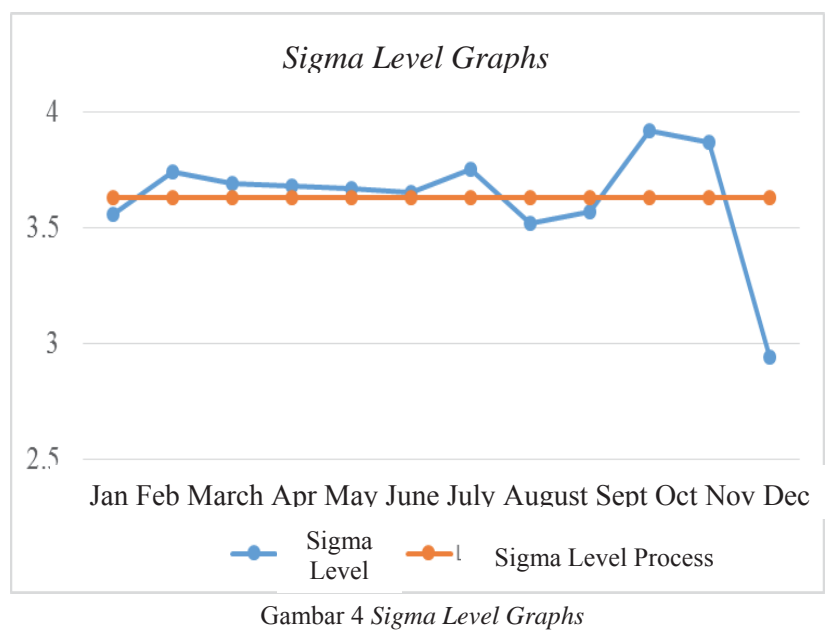

Tahap ketiga yang perlu dilakukan adalah menganalisis tahap yang akan menganalisis masalah rootcause yang terjadi di perusahaan. Dalam penelitian ini, analisis akan difokuskan di tiga rootcause yang akan digambarkan pada Gambar 5.
Untuk mengetahui akar masalahnya secara lebih rinci akan menggunakan alat diagram tulang ikan dan 5 kenapa analisis yang ditunjukkan pada Gambar 6.

\section{Types of Beans Defect}

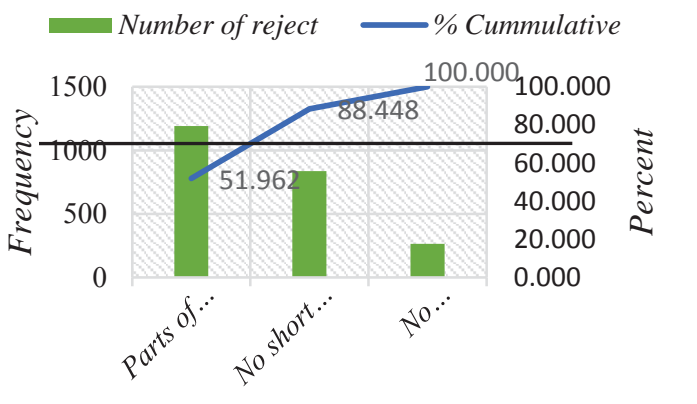

Gambar 5 Pareto Diagram for Broken Beans Defect Type

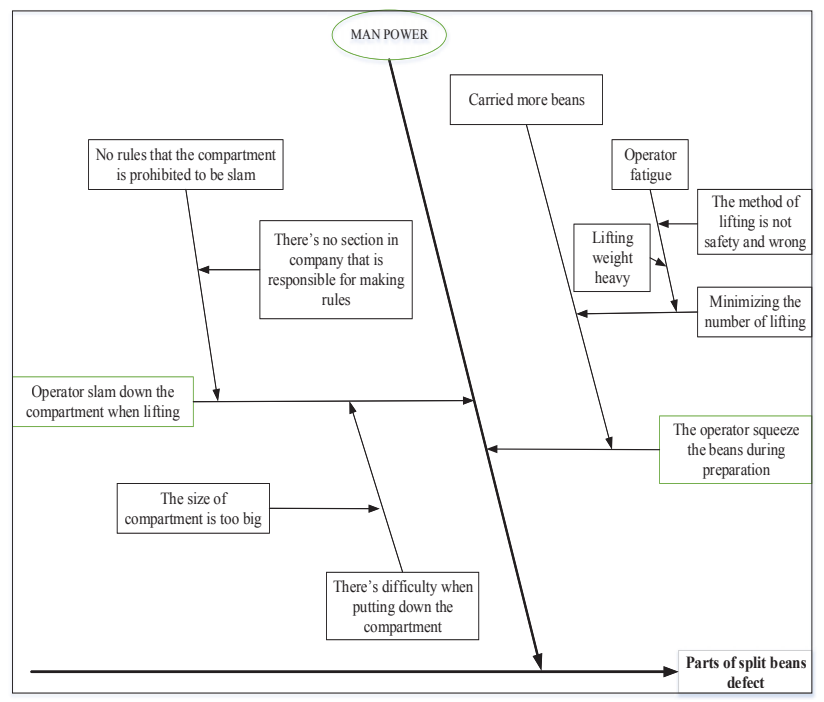

Gambar 6 Fishbone Cause Defects Parts of Split Beans

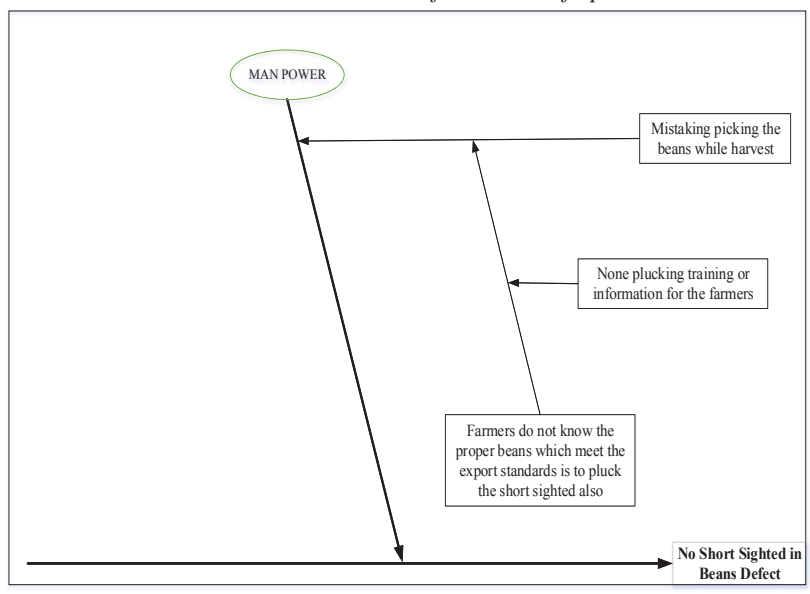

Gambar 7 Fishbone Cause Defect No Short-Sighted in Beans 


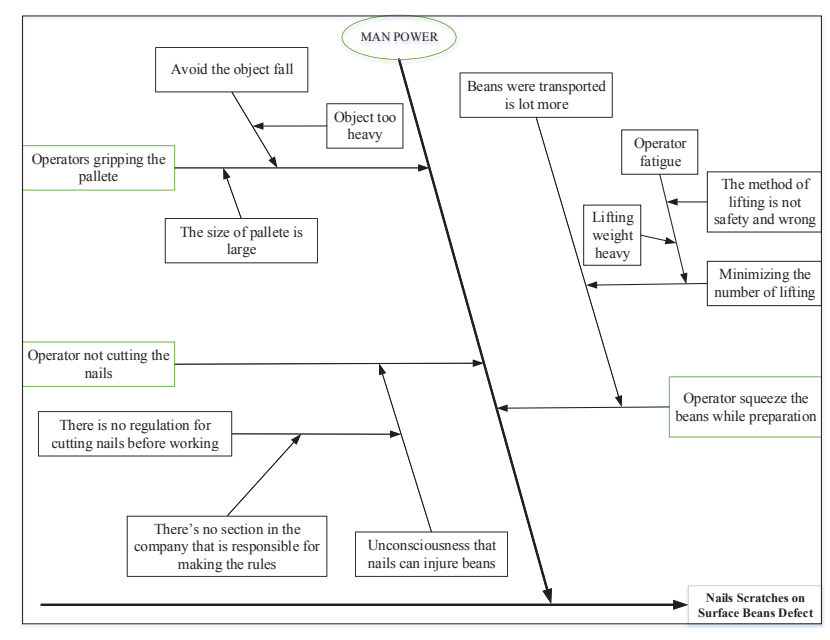

Gambar 8 Fishbone Chart of Disability Existence Scratches on Beans

Setelah mengetahui dan menganalisis akar penyebab cacat, tahap selanjutnya adalah meningkatkan tahap, yaitu untuk menentukan produk kacang rusak perbaikan prioritas. Prioritas perbaikan ini akan dilakukan dengan menggunakan FMEA (Failure Mode and Effect Analysis). Dalam penggunaan FMEA, kita perlu menentukan nilai atau skala keparahan, kejadian dan deteksi.

Dengan perjanjian dengan PT. Abo Pertanian dan analisis FMEA, penyebab kegagalan prioritas yang perbaikan berikut dapat dilihat pada Tabel 1 .

TABEL 1

ORDER RPN RESULTS

\begin{tabular}{|c|c|c|}
\hline Failure Modes & Causes of Failure & $\begin{array}{l}\text { RPN } \\
\text { values }\end{array}$ \\
\hline $\begin{array}{lr}\text { Torn } & \text { Trunk } \\
\text { section; There } & \text { Scratch } \\
\text { Nails } & \end{array}$ & The lifiting weight is too heavy & 560 \\
\hline $\begin{array}{lr}\text { Torn } & \text { Trunk } \\
\text { section; There } & \text { Scratch } \\
\text { Nails } & \end{array}$ & The method of lifting is not true & 560 \\
\hline $\begin{array}{lr}\text { Torn } & \text { Trunk } \\
\text { section; There } & \text { Scratch } \\
\text { Nails } & \end{array}$ & Large compartment size & 560 \\
\hline There Scratch Nails & $\begin{array}{l}\text { Gripping the compartment to avoid it } \\
\text { fall down }\end{array}$ & 560 \\
\hline $\begin{array}{lr}\text { Torn } & \text { Trunk } \\
\text { section; There } & \text { Scratch } \\
\text { Nails } & \end{array}$ & $\begin{array}{l}\text { There's no section in the company that } \\
\text { is responsible for making the rules }\end{array}$ & 490 \\
\hline No short-sighted & $\begin{array}{l}\text { The lack of information and training } \\
\text { plucking }\end{array}$ & 490 \\
\hline
\end{tabular}

Ada 6 (enam) potensi penyebab kegagalan yang akan menjadi pilihan dan prioritas perbaikan. Pemilihan dan prioritas perbaikan ini akan dilakukan dengan metode Kipling, sebuah metode yang terdiri dari serangkaian pertanyaan yang akan memperjelas masalah. Pertanyaan yang digunakan dalam metode Kipling adalah (1) Apa, apa tindakan perbaikan yang bisa dilakukan?, (2) Mengapa, mengapa tindakan korektif yang dilakukan?, (3) Dimana, dimana tindakan korektif yang dilakukan?, (4) Siapa , siapa yang melakukan tindakan perbaikan?, (5) Kapan, ketika tindakan korektif yang dilakukan?, (6) Bagaimana, bagaimana tindakan korektif dapat dilakukan?.

Berdasarkan hasil dari metode Kipling, diperoleh beberapa perbaikan yang diusulkan seperti yang ditunjukkan pada Tabel 2 berikut

TABEL 2

PROPOSED IMPROVEMENTS

\begin{tabular}{|l|l|}
\hline \multicolumn{1}{|c|}{ Penyebab Kerusakan } & \multicolumn{1}{c|}{ Bagaimana } \\
\hline $\begin{array}{l}\text { Beban yang diangkat terlalu } \\
\text { berat }\end{array}$ & $\begin{array}{l}\text { Menetukan beban } \\
\text { maksimum untuk operator }\end{array}$ \\
\hline $\begin{array}{l}\text { Metode pengangkatan beban } \\
\text { tidak sesuai }\end{array}$ & $\begin{array}{l}\text { Membuat metode standar untuk } \\
\text { pengangkatan beban yang } \\
\text { benar dan aman }\end{array}$ \\
\hline $\begin{array}{l}\text { Ukuran kompartemen yang } \\
\text { besar }\end{array}$ & $\begin{array}{l}\text { Menentukan ukuran } \\
\text { kompartemen yang ergonomis }\end{array}$ \\
\hline $\begin{array}{l}\text { Memegang erat-erat } \\
\text { kompartemen untuk } \\
\text { menghindari jatuhnya } \\
\text { kompartemen }\end{array}$ & $\begin{array}{l}\text { Menentukan beban maksimum } \\
\text { untuk pengangkatan operator }\end{array}$ \\
\hline $\begin{array}{l}\text { Tidak ada bagian di } \\
\text { perusahaan yang bertanggung } \\
\text { jawab untuk membuat } \\
\text { berbagai peraturan }\end{array}$ & $\begin{array}{l}\text { Menambahkan bagian di } \\
\text { perusahaan yang mempunyai } \\
\text { tanggung jawab untuk proses } \\
\text { kualitas dan kualitas produk } \\
\text { kacang }\end{array}$ \\
\hline $\begin{array}{l}\text { Sedikitnya informasi } \\
\text { mengenai pelatihan } \\
\text { pemetikan }\end{array}$ & $\begin{array}{l}\text { Mengadakan pelatihan } \\
\text { pemetikan untuk petani }\end{array}$ \\
\hline
\end{tabular}

\section{ANALISIS DAN PERANCANGAN}

Usulan perbaikan 1, menetapkan berat maksimum default, memiliki nilai RPN tertinggi yaitu 560. Dikutip dari pernyataan Organisasi Buruh Internasional, bahwa penghapusan beban oleh operator memiliki batas berat maksimal yang harus diperhatikan. Penentuan batas berat maksimum operator bawaan dapat memenuhi standar yang ditetapkan oleh Komisi Kesehatan dan Keselamatan dan NIOSH.

Penentuan batas berat maksimum untuk mengurangi risiko kelelahan operator yang dapat menyebabkan cacat pada kacang-kacangan. Oleh karena itu, solusi perlu dibuat agar pencabutan operator sesuai dengan standar. Alternatif solusi yang diusulkan adalah sebagai berikut:

Solusi: Memfasilitasi operator dengan alat peralatan mekanik pada saat lifting (operator bawaan berat tidak 
berkurang, bahkan bisa ditambahkan sesuai dengan kapasitas bantuan peralatan mekanik).

Alat angkat Ergonomi diperlukan untuk mewujudkan efektivitas dan efisiensi kerja. The National Institute for Occupational dan Komisi Keselamatan (Work aman Australia) telah membuat peraturan untuk penghapusan aman dari bahan, untuk mengangkat beban $>34 \mathrm{~kg}$ diberikan tindakan 'untuk dibantu oleh peralatan mekanik. Hal ini kontras tajam dengan keadaan yang ada di mana operator mengangkat bawaan seberat 50-55 kg secara mandiri tanpa bantuan alat peralatan mekanik.

Berdasarkan diskusi dengan perusahaan mengenai penggunaan alat bantu mekanik harus adalah memenuhi spesifikasi sebagai berikut. Ada (1) tidak meningkatkan jumlah operator yang bekerja di daerah pengumpulan, (2) untuk memudahkan pekerjaan operator dalam proses mengangkat, (3) dapat mengangkat lebih dari standar sebelumnya untuk semua removal (> 55kg per lifting).

Dari hasil dari spesifikasi yang disampaikan oleh perusahaan, peneliti mengusulkan bantuan peralatan mekanik dalam bentuk keranjang troli seperti yang ditunjukkan di bawah ini pada Gambar 9 dan Tabel 3 berikut ini akan menampilkan informasi produk di Platform Hand Truck Plastik KW05- 415 / KW0500415.

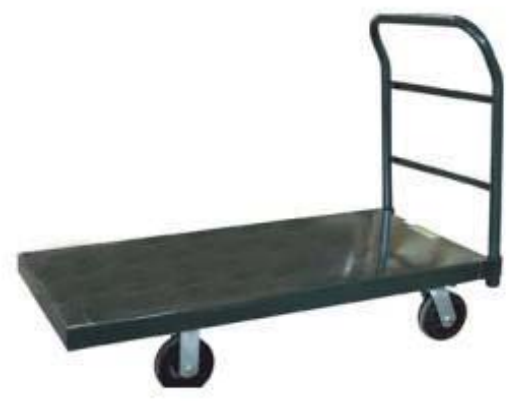

Gambar 9 Aid Proposed Mechanical Equipment (Hand Truck)

TABEL 3

SPESIFIKASI PRODUK PLATFORM HAND TRUCK PLASTIC KW05415/ KW0500415

\begin{tabular}{|l|l|}
\hline Spesifikasi & Detail \\
\hline Kapasitas Transportasi & $200 \mathrm{~kg} /$ travel \\
\hline Berat & $48,5 \mathrm{~kg}$ \\
\hline Panjang & $64 \mathrm{~cm}$ \\
\hline Lebar & $127 \mathrm{~cm}$ \\
\hline
\end{tabular}

Usulan perbaikan 2, menetapkan metode standar tentang cara penghapusan aman benar. Dalam dunia kerja, aktivitas mengangkat adalah materi pelajaran atau bisa disebut penting. Usaha yang dilakukan oleh lift jika tidak benar dan hati-hati dapat menyebabkan kecelakaan kerja dan penyakit akibat kerja. Yang ada, daerah kolektor kompartemen operator yang angkat tanpa melihat sisi keamanan tubuh saat mengangkat posisi tubuh. Untuk dapat melakukan pekerjaan dengan aman, seseorang harus memahami kekuatan tangan, kaki, dan tubuh dan bagaimana untuk mengambil posisi. Oleh karena itu, teknik mengangkat yang benar serta alat angkat ergonomis diperlukan untuk mewujudkan efektivitas dan efisiensi kerja.

Solusi: Petunjuk untuk menghilangkan objek (tidak tetap dalam satu objek) yang ada di meja / kantilever yang memiliki ketinggian.

Instruksi lifting adalah sebagai berikut (1) mengatur posisi beban yang akan diangkat di atas meja sehingga memudahkan ketika akan menaikkan, (2) tubuh dengan posisi jongkok sedikit menggunakan kaki sebagai tumpuan, (3) tangan kanan memegang bagian bawah beban dan tangan kanan memegang beban atas, (4) menempatkan beban di pundak terkuat dan bersandar di kepala, menghindari sudut tajam untuk dipukul di kepala, kemudian berdiri dengan hati-hati dan berjalan, (5) kami akan menempatkan beban kembali seperti cara mengangkat beban dalam urutan terbalik.

Pada gambar 10, itu menunjukkan tampilan untuk benda (apapun bentuk) yang memiliki ketinggian di atas meja.

\section{METODE PENGANGKATAN}

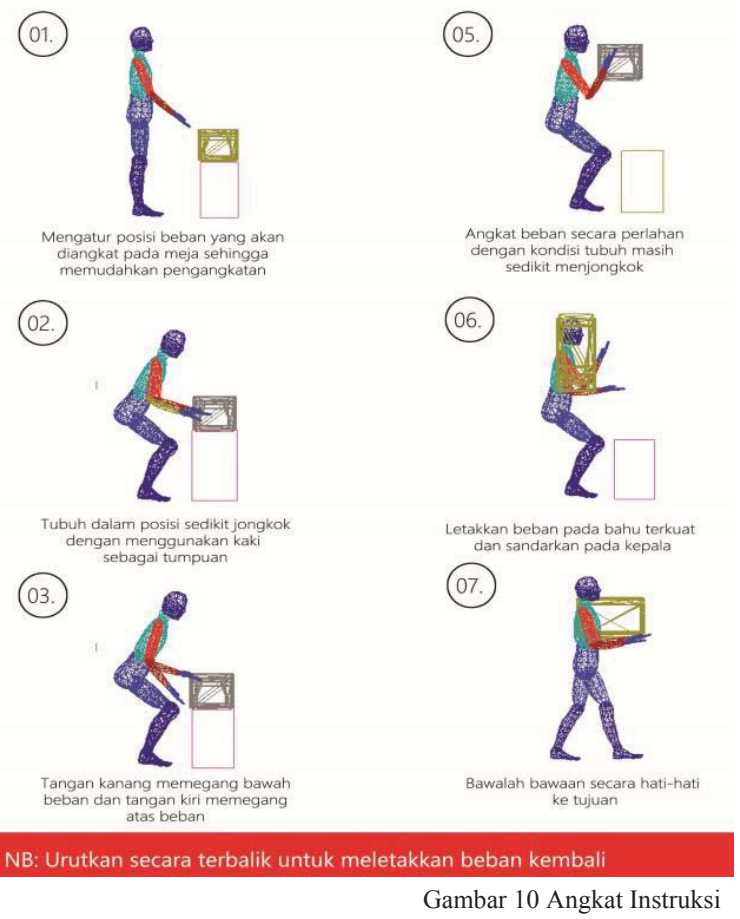

Display untuk Objek (semua jenis dan bentuk) yang memiliki ketinggian di atas meja 
Usulan perbaikan 3, menentukan ukuran ergonomis untuk kompartemen. Menurut Kohar Sulistiadi dan Sri Lisa Susanti (2003), fokus dari ergonomi adalah untuk meningkatkan kinerja seperti mengurangi kelelahan pekerja, mengurangi waktu yang terbuang dan meminimalkan kerusakan peralatan yang disebabkan oleh kesalahan manusia dan meningkatkan kenyamanan manusia dalam pekerjaan.

Solusi: Oleh karena itu perlu untuk merancang sebuah kompartemen ukuran yang memenuhi standar ergonomis yang telah ditetapkan namun tetap memperhatikan jumlah maksimum default berat yang dapat diangkat oleh operator.

Berdasarkan sisi ergonomis, panjang suatu benda dapat dikatakan jika ukuran yang sama ergonomis (tidak lebih besar dan tidak lebih kecil) dengan lebar bahu operator. Oleh karena itu, ukuran panjang kompartemen dapat diperoleh dari lebar bahu operator untuk 50 persentil dihitung dan ditunjukkan pada Tabel 4 sama dengan $47 \mathrm{~cm}$.

Di bawah ini ditunjukkan pada Tabel 5 ukuran kompartemen ergonomi direkomendasikan kompartemen lebar ketika mengacu pada dua (2) biji selaras.

TABEL 5

ERGONOMICS SIZE FOR COMPARTMENT WIDTH SUGGESTIONS WHEN REFFERING AT 2 (TWO) BEANS THE ALIGNED

\begin{tabular}{|l|l|l|}
\hline Kriteria & $\begin{array}{l}\text { Ukuran } \\
\text { (Container Beans) }\end{array}$ & $\begin{array}{l}\text { Ergonomic Size } \\
\text { Compartment }\end{array}$ \\
\hline Panjang & $44 \mathrm{~cm}$ & $47 \mathrm{~cm}$ \\
\hline Lebar & $34 \mathrm{~cm}$ & $37 \mathrm{~cm}$ \\
\hline Tinggi & $40 \mathrm{~cm}$ & $42 \mathrm{~cm}$ \\
\hline $\begin{array}{l}\text { Berat Maksimum } \\
(23 \mathrm{~kg})\end{array}$ & $21 \mathrm{~kg}$ & $2 \mathrm{~kg}$ \\
\hline
\end{tabular}

Usulan perbaikan 4, menambahkan kontrol kualitas (QC) departemen di PT. Abo Pertanian. Dalam sebuah perusahaan produksi mengambil bagian yang bertanggung jawab dalam pengendalian kualitas kualitas produk. PT. Abo Pertanian sebagai perusahaan yang memproses produk kacang dari pertanian untuk sampai ke eksportir harus menjaga kualitas produk agar tetap biji yang memenuhi syarat yang telah ditetapkan oleh eksportir.

Solusi: menambahkan bagian Quality Control at Pt. Abo Farm adalah solusi yang diusulkan untuk perbaikan yang diusulkan meminimalkan cacat yang terjadi di perusahaan.

Adapun penjelasan lebih rinci tentang alternatif perbaikan yang diusulkan untuk masalah ini adalah sebagai berikut:

Menambahkan bagian pada struktur organisasi perusahaan yang bertanggung jawab menindaklanjuti laporan tersebut menolak bagian Quality Control (Bagian Quality Control).
Peran dan Tanggung Jawab Seksi Pengendalian (Quality Control) adalah sebagai berikut (1) mengawasi dan mengendalikan biji kualitas produk dari proses penanaman, pemanenan, memilih, pengangkutan, pemilahan, pengepakan proses pengiriman ke kacang untuk eksportir, (2) menciptakan kebijakan yang berkaitan dengan perbaikan sistem manajemen mutu, (3) mengendalikan standar kualitas dan konsistensi ditetapkan untuk kepuasan pelanggan, (4) mencegah dan menghindari kerusakan produk buncis, (5) meningkatkan produksi dan mempertahankan citra produk kacang, (6) sebuah karya referensi dari batang dan perbaikan produk yang dihasilkan kacang.

The Job Description adalah (1) untuk memantau kinerja sistem kualitas, (2) pemantauan dan penilaian keluhan yang diperoleh dari eksportir, (3) menjembatani komunikasi antara pelanggan (eksportir) dalam hal penerapan standar ketenagakerjaan dan produk yang diminta oleh pelanggan, (4) menyusun kebijakan mutu perusahaan perusahaan, prosedur kerja, instruksi kerja yang berkaitan dengan penerapan sistem mutu perusahaan, (5) membantu proses analisis masalah yang terjadi dan mendiskusikan temuan materi kepada manajemen, (6) memberikan solusi untuk perbaikan kualitas produk biji, (7) melakukan pengawasan dan fungsi kontol dalam hal proses terkait dengan kualitas dan spesifikasi dari produk yang tersedia dalam kacang perusahaan, mulai dari menanam kacangshipment kepada eksportir, (8) menilai kinerja setiap proses dalam perusahaan.

Usulan perbaikan 5, melakukan pelatihan pemetikan. Pelatihan adalah proses yang terintegrasi yang digunakan oleh perusahaan untuk memastikan karyawan mereka bekerja untuk mencapai tujuan organisasi. Menurut Dessler (2009), pelatihan ini adalah untuk mengajarkan keterampilan yang dibutuhkan oleh karyawan baru dan yang sudah ada untuk melakukan pekerjaan itu. Tujuan dari pelatihan ini adalah untuk meningkatkan pengetahuan dan sikap karyawan dalam pekerjaan mereka sehingga output yang dihasilkan seperti yang diharapkan oleh perusahaan.

Solusi: Merupakan isi pelatihan dalam bentuk dokumentasi yang poster.

Dalam prakteknya, efektivitas pelatihan tidak akan 100\% berhasil jika ada petani yang berhalangan hadir. Oleh karena itu membuat poster untuk mewakili isi pelatihan bisa sangat efektif untuk semua target yang petani dapat membaca poster.

Isi poster sama dengan isi dari instruksi dan pelatihan adalah sejauh mana biji peringatan cupet harus memilih agar sesuai dengan standar yang ditetapkan oleh eksportir. Poster-poster akan ditampilkan dalam bentuk gambar sehingga petani akan tertarik membacanya. Dengan demikian informasi yang ingin disampaikan oleh perusahaan akan disampaikan secara jelas 
kepada petani. Berikut ini ditunjukkan pada Gambar 11 memilih usulan poster.

Poster ini akan ditempatkan pada bagian transportasi sementara petani dan pengumpul. Poster yang diusulkan, berukuran $290 \mathrm{~mm}$ x $210 \mathrm{~mm}$ yang telah disesuaikan dengan ukuran gambar dalam bentuk poster konten dan ukuran huruf. Desain poster pemberitahuan aturan memetik pilih font dan warna. Ukuran font untuk isi poster pesan diperoleh dari formula perhitungan berbasis visibilitas sejauh 1.5 meter. Penggunaan jarak visibilitas 1.5 meter adalah asumsi bahwa jarak adalah jarak terjauh tata letak poster dan posisi petani ketika mempersiapkan untuk tampil pada saat panen dan panen disimpan sementara.

Warna-warna yang digunakan dalam poster ini adalah warna yang menarik dan warna-warna yang bisa membuat sensitif, misalnya, penggunaan warna kuning pada poster ini karena warnanya adalah warna cerah dan dapat membuat mata kita untuk melihat.

Poster harus dibuat dalam bentuk stiker dalam rangka memfasilitasi instalasi pada titik pengumpulan dan para petani.

\section{"CUPAT REQUIREMENT" EXPORTER}

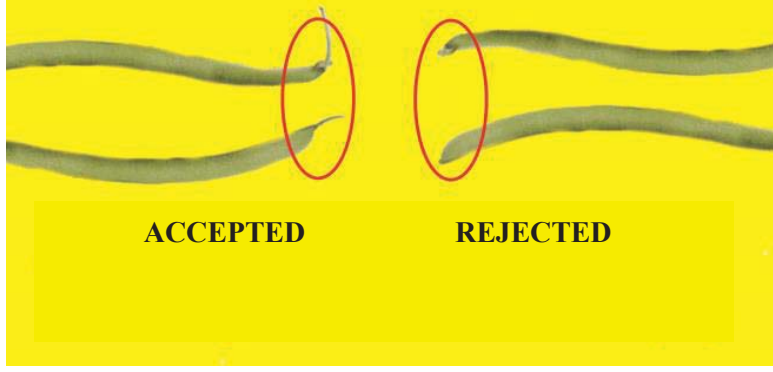

Gambar 11 Proposed Picking Process Display

\section{Kesimpulan DAN SARAN}

Berdasarkan hasil penelitian, dapat disimpulkan sebagai berikut (1) jenis cacat pada biji cacat fraktur dari Januari 2012 hingga Desember 2012 disebabkan oleh komponen yang rusak rusak kacang hijau, cacat akibat tidak adanya cupet dalam kacang dan cacat akibat goresan kuku pada permukaan biji, (2) faktor penyebab cacat biji rusak adalah sebagai berikut (i) cacat karena kacang poros split, (ii) cacat karena tidak ada cupet dalam kacang, (iii) cacat karena kuku goresan pada permukaan kacang, (3) perbaikan yang diusulkan direkomendasikan dalam penelitian ini dilakukan untuk semua penyebab kecacatan rusak kacang yang memiliki tinggi atau rendah nilai RPN (560 dan 490), yaitu: bawaan faktor, faktor yang tidak seberapa untuk mengangkat benar kompartemen, besar faktor ukuran kompartemen, mencengkeram faktor untuk menghindari bawaan jatuh, tidak ada salah satu faktor adalah bagian dari perusahaan yang bertanggung jawab dan bertanggung jawab untuk mengendalikan proses dan mengeluarkan larangan dan kurangnya pelatihan faktor pemetikan.Usulan perbaikan adalah (i) menetapkan operator berat maksimum default, (ii) menetapkan metode standar tentang bagaimana untuk memperbaiki dan penghapusan aman, (iii) menentukan ukuran kompartemen ergonomis, (iv) menetapkan standar operator berat maksimum, (v) menambahkan bagian di perusahaan yang bertanggung jawab atas kualitas dan kacang kualitas produk.

Rekomendasi penelitian ini diberikan bagi perusahaan dan peneliti selanjutnya. Rekomendasi untuk Perusahaan adalah (1) diberikan usulan harus dimasukkan dalam SOP sehingga dapat dilakukan secara terus menerus dan dapat diterapkan untuk semua jenis produk nabati, (2) dalam melaksanakan proposal dan pelaksanaan proyek-proyek Six Sigma, yang komitmen yang diperlukan dan keterlibatan manajemen puncak. Hal ini sangat penting karena pelaksanaan proyek-proyek Six Sigma memerlukan dukungan dari manajemen puncak, (3) manajemen perusahaan harus berpartisipasi mengingatkan petani dan pengumpul untuk selalu menggunakan instruksi kerja/layar petunjuk yang diberikan.

Rekomendasi untuk Peneliti Berikutnya adalah (1) dalam penelitian lebih lanjut, harus dilakukan secara bertahap sampai tahap Pengendalian DMAIC (Define-Measure-AnalyzeImprove-Control-Control) untuk mengetahui perbaikan yang direkomendasikan diusulkan untuk mencapai tujuan atau tidak, (2) dalam studi selanjutnya, harus dibahas dalam aspek lebih mendalam desain dengan memperhatikan beberapa elemen yang dapat membantu mencegah dan meminimalisir terjadinya patah kacang MSDS karena dalam penelitian ini pembahasan terbatas pada ukuran ergonomis pengeluaran kompartemen, (3) dalam studi selanjutnya, diskusi harus dilakukan pada metode / instruksi kerja kompartemen bila digunakan sesuai dengan desain baru, (4) dalam studi selanjutnya, pembahasan dapat dilakukan pada perbaikan yang diusulkan untuk mengurangi afkir jenis lain kacang PT. Abo Pertanian.

\section{DAFTAR PUSTAKa}

[1] Karyulianti, Tri Yanti. 2004. “Analisis Kualitas Pelayanan Jasa Paket PT.Pos Indonesia Menggunakan Metode Serqual dan Importance”. Tugas Akhir S1 Teknik Industri, Institut Teknologi Bandung.

[2] Pande, Peter dan Neuman, Robert. P dan Cavanago, Roland. R. 2000. The Six Sigma Way, Team Filedbook.

[3] Kotler, Philip. 2007. "Manajemen Pemasaran". Jakarta : Penerbit PT. Macanan Jaya Cemerlang. 